\title{
Renewing the Study of Public Sector Unions in Canada*
}

\author{
David Camfield University of Manitoba
}

\begin{abstract}
Résumé
Il est grand temps de faire une nouvelle étude du syndicalisme dans le secteur public. Cet article explique pourquoi les chercheurs devraient porter une plus grande attention aux syndicats du secteur public qu'ils ne l'ont fait jusqu'à ce jour ; il suggère aussi que la définition d'un nouveau cadre théorique, envisageant le syndicalisme contemporain non plus seulement comme une institution de relations humaines mais aussi comme un genre particulier d'organisation du mouvement ouvrier dans le contexte d'une formation historiquement spécifique de classe, serait bénéfique à l'étude des syndicats du secteur public. Il identifie également, partant de cette perspective, deux obstacles à la présentation de rapports sur le syndicalisme contemporain du secteur public.
\end{abstract}

\begin{abstract}
A renewal of the study of public sector unionism in Canada is long overdue. This article explains why public sector unions deserve more attention from researchers than they have received of late and proposes that studies of public sector unions would benefit from adopting a new theoretical framework that conceptualizes contemporary unions as not only labour relations institutions but also as particular kinds of working-class movement organizations within a historically-specific class formation. It also identifies two obstacles to the production of accounts of contemporary public sector unions from this perspective.
\end{abstract}

\footnotetext{
* An earlier version of this article, prepared as part of a project supported by the University of Manitoba Research Grants Committee, was presented to a joint session of the Society for Socialist Studies and the Canadian Industrial Relations Association at the University of Manitoba in June 2004. My thanks to the journal's anonymous reviewers for their comments.
} 


\section{Introduction}

Public sector unions play a pivotal role in labour relations and the labour movement in Canada today. Events in the spring of 2004 demonstrated this clearly, with a four-week public sector strike in Newfoundland and the strike by over 40,000 hospital and long-term care workers in British Columbia (and the day of illegal walkouts by some 18,000 other workers in support of them) that threatened to trigger a general strike in the province. The role of public sector unions in leading public protests against Jean Charest's Liberal government in Quebec is also notable. But what kinds of organizations are these unions, and how should we study them? If scholars want to understand the qualities of public sector unions today, their "objectives, character and ideologies" (Murray, 2002: 115), we need a strong body of theoretically-informed empirically-grounded research. Unfortunately, such research is sorely lacking.

A renewal of the study of public sector unionism is long overdue. Developing a powerful theoretical approach for this kind of research is a vital first step. This article makes a case for why public sector unions in Canada deserve more attention from researchers than they have received of late, proposes that studies of public sector unions would benefit from adopting a new theoretical approach that considers them as a particular kind of workingclass movement organization within a historically-specific class formation, and identifies two obstacles to the production of the kind of studies of contemporary public sector unionism that we need today.

\section{Why a Renewal of Research on Public Sector Unions?}

The importance of public sector unions in Canada is obvious in a quantitative sense. A shrinking minority of workers are employed in the broad public sector, $22.3 \%$ in 2002 , but public sector unionists represent 53.5\% of all union members (Levesque, 2003; Akyeampong, 2004: 7). Public sector workers are four times more likely to be union members than are private sector workers (Akyeampong, 2003: 2). Workers in Canada with direct personal experience of union membership are more likely to be employed in the public sector. With the density rate in the private sector falling, popular impressions about the nature of unions are in part produced by a labour movement that is, in its majority, made up of public sector workers.

At least as significant as this is the way that the nature of unionism in Canada has been influenced by the prominence of public sector workers within the labour movement. This influence has been exerted in at least three major ways. Most obviously, with more than half of all unionists working in the public sector, their unions have considerable weight within the labour centrals.

Second, since the early 1990s some (but by no means all) public sector unions have 
distinguished themselves from the rest of the labour movement — with the important exception of one private sector union, the Canadian Auto Workers (CAW) - by their commitment to campaigning publically and sometimes mobilizing their members against neoliberal policies. In Ontario in the early 1990s, public sector unions along with the CAW opposed the NDP government's Social Contract. This public sector-CAW bloc went on to spearhead the Days of Action against the provincial Conservative government between 1995 and 1998 (Camfield, 2000; Panitch and Swartz, 2003). Similarly, public sector unions were the key players in the Day of Disruption across Quebec on Dec. 11, 2003 (Séguin, 2003). Through such extra-parliamentary action as well as many other campaigns, mobilization unionism and social movement unionism in the labour movement have been strengthened, though it must be emphasised that this process has been uneven across and within public sector unions. ${ }^{1}$ This experience is not unique to Canada. Public sector unions have been at the forefront of resistance to neoliberalism globally (Moody, 1997: 272-273).

A third way in which public sector unions have influenced the labour movement as a whole arises from their particular gendered character. Many of the jobs created by the expansion of the public sector during the long post-World War II economic boom were filled by women. "As nurses, teachers, civil servants at the federal and provincial levels, municipal workers, and employees in schools and hospitals joined unions, the impact on the organized labour movement and on advancing the interests of women has been profound" (Luxton and Reiter, 1997: 209). In 2003, 60.7\% of employees in the broad public sector were women, compared with $45.4 \%$ in the private sector and $48.9 \%$ overall. ${ }^{2}$ Despite job cuts, the public sector remains an important source of better-paid jobs for women wage-earners. Since the 1960s, the growth of women's participation and leadership, including the efforts of conscious feminists, has had a significant impact on the priorities and practices of public sector unionism, even if the changes achieved have been less than many feminist union activists desire (Briskin, 1999; Luxton, 2001; Warskett, 1996; White, 1993). In English Canada at least, by far the most prominent woman union leader in recent years has been Judy Darcy, who served as National President of the Canadian Union of Public Employees (CUPE) from 1991 to 2003. Public sector union women have been at the forefront of pushing for policies, constitutional changes, education and mobilization to challenge sexism, racism and heterosexism in society and within the labour movement (Luxton and Reiter, 1997). Such activity emerges from years of much lower-profile work by women activists in public sector union locals, such as

\footnotetext{
${ }^{1}$ Here I am making a distinction between two forms of union praxis that are often conflated in discussions of social movement unionism. Mobilization unionism is committed to building active unions, has a broad social justice orientation, and is willing to use militant tactics. It advocates worker participation in contract administration and union campaigns, but this is not the same as democratic member control (Parker and Gruelle, 1999). Social movement unionism is distinguished from mobilization unionism by the way it places democratic membership control at the centre of efforts to build union power.
}

${ }^{2}$ Calculated from data from Statistics Canada (Levesque, 2004). 
bargaining for better parental leave provisions, anti-harassment contract language, and rights for lesbian and gay workers (Hunt, 1997).

Another development that should draw our attention to public sector unions is the extensive restructuring of all levels of the state in recent years. ${ }^{3}$ This raises the question of whether unions have in any way affected the restructuring of the state and, if so, in what ways. The presence of a highly-unionized work force in the midst of the reengineering that is altering the shape of public services and public administration in Canada is another reason why more analysis of public sector unionism is needed.

Thus public sector unions are important because of the high union density in the public sector that makes them a majority of the union movement, their influence on organized labour as a whole, and their location in the midst of contemporary state restructuring. Their centrality will probably persist unless large-scale privatization and contracting-out leads to a massive reduction in public sector employment. Some may question this prediction by pointing to the decline of the public sector workforce in absolute and relative terms. It is true that employment in the broad public sector fell from 3.06 million (108 per 1000 population) in 1992 to 2.84 million (91 per 1000) in 2002 (Statistics Canada, 2002). This is a significant but not abrupt decline; there is no indication that wholesale privatization is about to dramatically reduce the size of the public sector workforce in a way that would quickly reduce the importance of public sector unions.

That said, aggressive measures that slash union density within the public sector would seriously weaken the influence of public sector unionism. This has been the experience in a number of countries. For example, changes to the labour relations regime in Australia led to the number of union members in the public sector plummeting by $41 \%$ between 1992 and 2001, resulting in a plunge in union density in the sector from $67.1 \%$ to $47.9 \%$ and a reduction of the public sector's share of total union membership from $45.9 \%$ to $36.2 \%$ (Anderson, Griffin and Teicher, 2002: 65, 66). However, there is no indication that the government of any Canadian jurisdiction is planning to implement measures that would have a similar impact. The highly aggressive approach of British Columbia's Bill 29 of 2002, "arguably... the most severe government intrusion into collective agreements in Canadian history" (Thompson and Bemmels, 2003: 108), which stripped successor rights from hospital and long-term care facility workers belonging to the Hospital Employees Union as a prelude to large-scale contracting-out has not been generalized even in BC. Thus far, neoliberal governments in Canada have remained content to restructure without aggressively trying to lower union density within the public sector.

A quite different development that would probably begin to reduce the centrality of public sector unionism in the labour movement would be a resurgence of organizing in the private

${ }^{3}$ See for example: Shields and Evans (1998); Jessop (1994); McBride and Shields (1997); Sears (1999); Teeple (2000). 
sector. Even in the absence of union expansion, the development of greater dynamism within one or more private sector unions might also have this effect. However, neither seems likely in the short term. ${ }^{4}$

\section{Theorizing Unions in the Public Sector}

To renew the study of public sector unionism in contemporary Canada, we need theory that has at least an adequate grasp of the phenomena in question so we can conceptualize them and avoid the problems of under- or inappropriately-theorized research. These problems are evident in studies concerned with the institutions, processes and outcomes of labour relations which treat unions exclusively or primarily as labour relations institutions (e.g. Swimmer, 2001; Ilcan, O'Connor and Oliver, 2003; Hebdon and Mazerolle, 2003). They are also present in much of the limited amount of work that has been done in recent years on public sector unions themselves. Yonatan Reshef and Sandra Rastin's Unions in the Time of Revolution (2003) contains interesting material on public sector union struggles with neoliberal governments in Alberta and Ontario during the 1990s, but suffers from major theoretical weaknesses in its treatment of worker conservatism and apathy (Camfield, 2004b). David Rapaport's book on the 1996 Ontario public service strike (Rapaport, 1999) is a detailed descriptive account without analytical and theoretical depth. The one book which stands out as an exception is Gillian Creese's Contracting Masculinity: Gender, Class, and Race in a White-Collar Union, 1944-1994 (1999). Its focus is squarely on understanding the historical development of the office workers' union at $\mathrm{BC}$ Hydro to illuminate how it has been shaped as an organization, and Creese attempts an integrated critical analysis of the social relations of class, gender and race that have moulded the union. Its focus and its theoretical perspective are noteworthy and distinguish it from most recent research that deals with public sector unions in Canada.

Obviously, contemporary Canadian unions are legally constituted as labour relations institutions, and this must not be dismissed; it is on this basis that they are subjects of rights and objects of political administration. ${ }^{5}$ Yet unions are more than legaladministrative entities. They are also workers' organizations (Kelly, 1998; Hyman, 1975). As Richard Hyman has argued:

trade unionism provides a good example of the way in which a purely institutional perspective can be dangerous and misleading... what does it mean to say that "the union" adopts a particular policy or carries out a certain action? This is a clear instance of... reification: treating an impersonal abstraction as a social agent, when it is really only people who act (1975: 16).

\footnotetext{
${ }^{4}$ Despite considerable discussion and the allocation of somewhat more union resources to organizing, private sector density is not rising. See Rose and Chaison (2001) and Yates (2000). Nor is there much evidence of reform from above or below inside private sector unions. Some innovative developments are discussed in Bickerton and Stearns (2002), Cranford and Ladd (2003) and Tufts (1998).
}

${ }^{5}$ On rights and political administration, see Neocleous (1996). 
A rare example of research on public sector unions that explores them as workers' organizations is Paul Johnston's study of several US public sector unions in California in the 1970s and 1980s, Success While Others Fail (1994). Johnston also emphasizes that unions in the public sector are distinct from those in the private sector because they operate in the qualitatively-different context of the state or, as he prefers to call it, "public organization" (4). This structural location, he argues, provides public sector unions with different power resources. Private sector unions rely primarily on market power, while public sector union power largely derives from:

\begin{abstract}
first, legal rights, organizational status and established procedures; second, strategic alliances within the shifting political universe of the public agency, including clients, constituents, and other participants in that political universe; third, forms of voice that can help mobilize new organization, build or prevent alliances, and, by framing and appealing to "the public interest," put a potent political edge on the workers' demands (11).
\end{abstract}

Their context also gives public sector workers' movements a specific kind of identity and shapes their demands and objectives (29). Public sector union demands "tend to assume a distinctly political-bureaucratic rather than commodified form" (12). They tend to be presented as legitimate public needs, not private claims. These aims and demands make public sector unions "perhaps the quintessential 'state-building' social movement" (14).

Underpinning this analysis of the distinctive context of public sector unionism is a theory of the state. For Johnston, the state is public organization, which is "the political solution to the problem of collective action" (31). It "claims a monopoly, for a defined jurisdiction, on the ability to set and implement public goals" (31). Public organization is structured as the producer of "politically defined and administrable public goods" (30). There is no true definition of what constitutes the public good, only a constant struggle over its official definition, involving many interest groups, including those whose private interests are rooted in their place in public organization itself (31). Unions of public sector workers exist as an element of this administrative complex, which determines their resources and demands.

Johnston's work is a rare example of an effort to theorize public sector unions as a specific kind of workers' organization, not just as industrial relations institutions. However, it does not provide the theory we need to inform new research on public sector unionism in Canada. One limitation is its suggestion that public sector unions exist in a sphere that is entirely different from that of their private sector counterparts because public organization is radically unlike the labour market environment of private sector workers and their unions. However, the dualism of state and capital implicit in this view is superficial and cannot be sustained. To argue this is not to deny that states are different from private firms, 
or that public and private sector labour markets differ, or that public and private sector employment relations are not identical. States in capitalist societies are organizationally distinct, but they do not exist outside of capital. In capitalist societies, state power is internally-related to capital: "both its existence as a material force and the forms of its social intervention are subordinated to the need to secure the expanded reproduction of capitalist social relations of production" (Clarke, 1983: 123).

This is not an irrelevant debate in state theory. Johnston's theory of the state leads him to conceptualize the structural context of public sector unionism as fundamentally outside capital; the alternative perspective summarized above offers a more nuanced understanding that can help us to understand the public sector in the era of neoliberalism (Sears, 1999). Johnston also misses a crucial source of power for some public sector unions: the ability to bring state activities to a halt by striking. For many public sector workers, this is a structural capacity which they possess whether or not they have the legal right to strike; its exercise not only disrupts the provision of services but throws a wrench into the state's political administration of civil society. The three power resources of public sector workers that Johnston mentions may have been commonly-used by the workers he studied, yet they do not include the most potent power resource of public sector unions.

If Johnston's theory of public sector union power is inadequate, his discussion of the demands and identity of such unions is more useful. It captures something of the tendency for the self-understandings of public sector unionists to be conditioned by their labour of service delivery. Similarly, public sector union demands are often presented as being in the "public interest" rather than as private claims. In Canada in recent years, educational workers have argued that their working conditions are students' learning conditions; health care workers have often linked their concerns about workload, scheduling, stress and morale to the quality of patient care. If Johnston is right here, his observations about public sector unionism as a 'state-building' movement need to be supplemented by points made by Greg McElligott. Public sector workers sometimes exercise their discretion to affect the way in which state activity happens. They may hinder the implementation of policies which they find objectionable or contrary to their own interests. In the case of front-line workers, their everyday interactions with 'clients' may influence how they do the labour of political administration. The union at the centre of McElligott's study, the Canada Employment and Immigration Union (part of the Public Service Alliance of Canada), went beyond individual acts of defiance and adopted a political strategy that involved building coalitions with unemployed workers as well as direct action on the job (McElligott, 2001: 162-187). This suggests that public sector unions do not necessarily simply 'build' the existing state; they may in fact try to change it.

Despite its weaknesses, Johnston's work clearly recognizes that public sector unions are 
workers' organizations as well as legal-administrative entities. His attempt to theorize them raises the important issue of their distinctive relationship with the state as employer, a relationship which is bound to be affected by changes in the form of the state. If the preceding discussion clarifies something of the nature of these unions as organizations of public sector workers, what about their character as working-class organizations?

\section{Theorizing Unions as Working-Class Movement Organizations}

There is a great deal more involved in understanding unions as working-class organizations than simply acknowledging that union members are wage-earners. The heart of the matter is how we understand class. ${ }^{6}$ Ellen Meiksins Wood contends that "there are really only two ways of thinking theoretically about class: either as a structural location or as a social relation" (1995: 76), and makes a powerful case for understanding class as a relational and structured process in time. If we are interested in understanding reallyexisting unions in capitalist societies, it is not enough to consider class relations as they exist at a given moment. This synchronic sense of class relations is what Wood refers to as class situation. "The point," she writes, "is to have a conception of class that turns our attention to precisely how, and in what different modes, objective class situations matter" (83).

This means that we need to concern ourselves with "the complex and often contradictory historical processes by which, in determinate historical conditions, class situations give rise to class formations" (83). Class formations develop through the relations people have to the conditions of production and other classes. As working-class organizations, unions past and present need to be considered in relation to historically-specific class formations. This requires that we adopt a diachronic theoretical approach, one that takes seriously the reality that unions (like other social phenomena) are not ahistorical but exist in time (Abrams, 1982). It follows that contemporary unions deserve the same depth of scrutiny that historical researchers accord to unions that have long since left the stage of labour relations.

A trio of concepts can assist in the study of unions as organizations belonging to particular class formations: class composition, decomposition and recomposition. The first refers to the relations within a working class as it exists in relationship to a certain structure of production. The divisions and hierarchies that exist within the class thus become an integral part of class theory. The aim of looking at a class formation in this way is to produce "a disaggregated picture of the structure of class power existing within the division of labour associated with a particular organisation of constant and variable capital" (Cleaver, 1992: 113). The analysis of class composition can be said to have four dimensions. One is the study of "struggles themselves: their content, their direction, how

${ }^{6}$ This section draws on Camfield (2004a). Although public sector workers are not always recognized as working-class by scholars or themselves, for strong arguments that they ought to be see Meiksins (1986; 1987). 
they develop and how they circulate" (Zerowork Collective, 1992: 111). Another is the relations between different sections of the class (including the unwaged), "the way these sectors affect each other and thus the relation of the working class with capital" (111). This makes divisions and inequality among workers, reflected above all in different wage levels (111), a key issue. The third dimension is the relations between workers and their organizations, including unions. Finally, "all these aspects have to be related to the capitalist initiative in terms of general social planning, investment, technological innovations, employment and to the institutional setting of capitalist society" (112).

The concept of recomposition refers to activities which unite workers as a class against capital. By reducing divisions among workers, the balance of forces is shifted in workers' favour. In response, capital attempts to break down the growing unity among workers in order to reimpose control and establish a new class composition favourable to itself. This may involve work reorganization, new technology and a new division of labour as well as the state's fiscal, monetary and social policy. This is decomposition. These concepts highlight the ongoing struggle between workers and capital, in which workers at times attempt to recompose themselves as a class to meet their needs and capital responds with strategies of decomposition. With the dynamic concepts of recomposition and decomposition and the static concept of class composition it is possible to analyse the cycles of class conflict that characterize the history of capitalism (Cleaver, 1992: 114). Note that in the use of these concepts to analyse processes of class formation it is the effects of actions that are crucial, not the intentions and motivations of agents.

Much as these concepts can be very useful for the study of unions as working-class movement organizations, they will remain inadequate if they are not incorporated into an understanding of class as a mediated social relation. Class is mediated through all other social relations, and vice versa. In other words, other social relations are not epiphenomena of class. What Stuart Hall and his co authors write about race - that it is "the modality in which class is lived" and "the medium in which class relations are experienced" (Hall et al, 1978: 394) - is true, and not only of race but of all social relations that simultaneously mediate class. To say that class is mediated by other social relations means that it does not exist outside of them. Class is not initially constituted in pristine isolation and then brought into contact. On the contrary: the relationships between class, race, gender and other social relations are internal. Consequently, a host of social relations need to be considered in the study of unions as movement organizations belonging to a class formation. Relations of gender, race, nation, sexuality and space are all interwoven with class. Workers' social existence is shaped by these and potentially other influences. Every class formation is affected by how social relations other than those of class are ordered. As a result, workers' identities have facets other than class, though these do not take shape outside of class. Workers' experiences of class itself will vary depending on where they are positioned vis 
a vis other social relations. To those who do not wear theoretical blinders, the multidimensionality of social being is evident in working-class action and consciousness. Class must be studied concretely, with the understanding that social reality is multidimensional. In other words, class is never only about class.

\section{A Framework and Issues for Research}

What I am proposing, then, is to theorize contemporary public sector unions in Canada in a historically-grounded way, as working-class movement organizations of a distinct kind that belong to a particular class formation. Placing unions within the broader field of social relations of a class formation can be thought of as akin to expanding the study of icebergs beneath the ocean's surface into the depths below. Every union is shaped in very significant ways by the class formation to which it belongs, whether or not researchers care to inquire into how this happens. For example, workers' orientations to unions are not solely determined by their immediate workplace circumstances or the actions of employers and union officials. They are influenced by, among other things, social experiences and traditions of the past and present. Much work needs to be done to analyze the workingclass formation on Canada today, but we can safely say that it has undergone a significant degree of decomposition as a result of neoliberal state policies, including new forms of labour market regulation, and the lean reorganization of labour processes, both of which have been justified with claims about the need to increase Canadian competitiveness and, in the case of the public sector, reduce spending. This decomposition has definite gendered and racialized dimensions. For example, the contracting-out of health care support work in British Columbia that led to the important 2004 strike of the Hospital Employees'Union (HEU) disproportionately affected women workers of colour, but some better-paid white tradespeople in HEU along with some HEU nurses and workers in technological classifications did not believe their jobs were threatened and were more concerned with their wages than with fighting for protection against privatization (Camfield, forthcoming). Decomposition is reflected in the "growing consciousness of resignation to and acceptance of the status quo" among working-class people, "resulting in a search for individual solutions" (Brennan, 2005: 47) rather than collective ones. The Canadian working-class movement, long-bureaucratized, is divided (with a public-private split being one important fissure) and retreating, though not routed (Brennan, 2005; Lamb, 2004). Public sector unions have a distinct character. They are legally constituted as collective bargaining institutions in accordance with the mode of industrial legality that was originally forged in the class struggles of the 1940s and then amended in response to public sector workers' militancy and organizing of the 1960s and 1970s to confer rights and obligations on public sector unions, in an inequitable, inconsistent and generally restrictive manner (Panitch and Swartz, 2003). As unions not only regulated by capitalist state power but representing workers employed by state agencies and state-funded organizations, public sector unions have been shaped by the form of that state power, 
which has shifted as the broad welfare state of the long post-war boom evolved through the piecemeal restructuring that followed the end of the boom into the lean state of today. Public sector unions have sometimes resisted this restructuring, with only limited success (Camfield, 2005).

Using this framework to study Canadian public sector unions would open up dimensions of unionism that are often passed over or which receive little attention in research that has a narrower institutional focus. The insights yielded by deepening the study of unions in this way ought to supplement rather than obscure attention to how employers, employment relations and state regulation shape unions. Adopting this approach to research on Canadian public sector unions should allow us to develop a much richer understanding of their specific qualitative features, and thus of how they have acted and are likely to act in the future.

For example, our understanding of Canadian labour would be much-enriched by a major study of the growth of public sector unions in Canada in the 1960s and 1970s that placed this development within the context of a decade-long recomposition of the working-class formation and the building of the broad welfare state. This era saw high levels of legal and illegal strikes and other forms of workplace conflict, which emerged within and sometimes against the kind of unionism forged in the 1940s; this was also an era of youth revolt, 'Second Wave' feminism and an upsurge of Quebec nationalism, and of the twilight of the long post-war economic boom that underpinned low unemployment, rising living standards and expectations, the growth of women's participation in paid work, and the expansion of the public sector (Heron, 1996; Palmer, 1992). Such a study could reveal much about specific forms of worker activity, consciousness and organization that put their stamp on public sector unions in their formative years. Such knowledge would help us to understand the different ways that public sector unions have responded to changes in labour relations in the phases of public sector collective bargaining since the arrival of widespread restraint in the early 1980s.

The study of contemporary public sector unions from this theoretical perspective faces two kinds of obstacles. First, the contours of class formation and the broad working-class movement, within which any given union organization and its members needs to be situated, are in need of illumination. There is plenty to be done in terms of synthesizing the many pieces of relevant existing research on paid workplaces, communities and households and, by theoretically reflecting on these concrete studies, constructing generalizations (provisional, to be sure) about the character of the working-class formation as a whole and of the workers' movement in Canada. Research on public sector unions will benefit from being able to position these unions within these broader fields; it will, in turn, enhance our understanding of the class formation and working-class movement by 
contributing more concrete knowledge of their public sector components.

The second obstacle is that recent empirical research on public sector unions is inadequate; we cannot simply take what has been done and reinterpret it with this new theoretical perspective to produce an adequate account. This is because we know quite a lot about the wage outcomes of collective bargaining and the political administration of public sector unions (e.g. Swimmer, 2001; Panitch and Swartz, 2003; Rose, 2004), but very little about other important aspects of public sector unionism. These aspects, which I place under three headings, need to be explored; studies of these issues will help in the construction of more complete accounts using the framework presented here.

\section{Changing Labour Processes and Public Sector Unionism}

Workers and their unions are fundamentally affected by the organization of waged work. It is commonly acknowledged that labour processes have changed significantly as governments and state managers have been restructuring the public sector in incremental or more comprehensive ways. However, we know very little about these changes and what they have meant for workers and their unions. We need studies whose focus is not on public administration policy or human resource management practices in the public sector but on how work has actually been reorganized in different public sector workplaces, how workers have experienced workplace change, how this has affected their relations with unions, and how unions have responded. Some research on public sector labour processes has been conducted with an eye to the relationship between work organization and health (e.g. Baines et al, 2002, Lewchuk, 2002), but such studies have paid little attention to how work reorganization has affected the ways workers relate to their unions and the reactions of union officials, staff and activists.

\section{Public Sector Workers and their Unions}

The relationship between workers and unions is a critical issue for understanding the character of union organization. This raises questions about the orientation of workers to the unions that represent them. The level of worker involvement and workers' attitudes to their unions (at the workplace, local and higher levels) on an everyday basis, around collective bargaining, and at times of heightened tension or conflict all deserve investigation. Relations between union officials, rank and file activists and other workers are one aspect of this subject. Divisions, privilege and inequality among unionized workers are another aspect. Here it is necessary to be carefully attuned to the issue of bureaucracy, understood, as Hyman has proposed, in terms of "the differential distribution of expertise and activism... the dependence of the mass of union membership on the initiative and strategic experience of a relatively small cadre of leadership - both 'official' and 'unofficial"' (Hyman, 1989: 158). 


\section{Public Sector Union Praxis}

Specific combinations of union activity and ideology, including the character of union leadership (Barker, Johnson and Lavalette, 2001), can be called modes of union praxis. In Canada, arguably four such modes can be identified: business unionism, social unionism, social movement unionism, and what I have elsewhere called mobilization unionism (Camfield, 2005). Although we know more in broad terms about public sector union praxis than about the above-mentioned issues, our knowledge is by no means adequate. One of the reasons for this is the tendency to make too much of formal union policies and pronouncements. Because unions are, above all, what they do, actual forms of union activity need to be studied, along with official and unofficial ideological statements and outlooks. This needs to be done at different scales, from that of national unions to locals to workplaces.

\section{Conclusion}

Public sector unions account for more than half of all union members in Canada. They will probably continue to do so as long as union density continues to decline in the private sector. Conflict between public sector unions and neoliberal governments will likely persist and may become more common as state restructuring continues. Within the labour movement, public sector unionists, many of them women, have been active in campaigns and mobilizations, in such efforts to challenge sexism and other forms of oppression within organized labour as have taken place to date, and in building alliances outside the workplace. Clearly, these unions are significant organizations. Yet our knowledge of public sector unionism today is often impressionistic or derived from institutional studies that do not reveal much about the character of union organizations. To remedy this weakness will require empirically-grounded research which appreciates that unions are much more than labour relations institutions. The theoretical approach outlined in this article, which conceptualizes public sector unions as historically-specific working-class movement organizations of a particular kind, is intended as a contribution to the renewal of the study of public sector unionism in Canada that is needed today. 


\section{REFERENCES}

Abrams, P. 1982. Historical Sociology. Ithaca: Cornell UP.

Akyeampong, E.B. 2004. "The Union Movement in Transition." Perspective on Labour and Income (Statistics Canada Catalogue no. 75-001-XIE), Vol. 5, No. 8, pp. 5-13.

Akyeampong, E.B. 2003. "Fact Sheet on Unionization." Perspectives on Labour and Income (Statistics Canada Catalogue no. 75-001-XIE), Vol. 4, No. 8, pp. 1-25.

Anderson, E., Griffin, G. and J. Teicher. 2002. "The Changing Roles of Public Sector Unionism." International Journal of Employment Studies, Vol. 10, No. 2, pp. 47-81.

Baines, D., Hadley, K., Slade, B., Fay, K., Pollack, S., Brooker, A.S., Preston, S., Lewchuk, W., and D. Dimatrova. 2002. Improving Work Organization to Reduce Injury and Illness: Social Services, Stress, Violence and Workload. Hamilton: Institute for Work in a Global Society.

Barker, C., Johnson, A. and M. Lavalette. 2001. "Leadership Matters: An Introduction." In Leadership and Social Movements. C. Barker, A. Johnson and M. Lavalette (eds.). Manchester: Manchester University Press, pp. 1-23.

Bickerton, G. and C. Stearns. 2002. "The Struggle Continues in Winnipeg: The Workers Organizing and Resource Centre.” Just Labour, Vol. 1, pp. 50-57.

Brennan, B. 2005. "Canadian Labor Today: Partial Successes, Real Challenges." Monthly Review, Vol. 57, No. 2, pp. 46-61.

Briskin, L. 1999. "Feminisms, Feminization, and Democratization in Canadian Unions." In Feminist Success Stories. K.A. Blackford, M. Garceau and S. Kirby (eds.). Ottawa: University of Ottawa Press, pp. 73-91.

Camfield, D. Forthcoming. "Neoliberalism and Working-Class Resistance in British Columbia: The Hospital Employees' Union Struggle, 2002-2004.” Labour/Le Travail. 
Camfield, D. 2005. "Canadian Public Sector Unions: Neoliberal Challenges and Union Renewal." Revised version of a paper presented at the Colloquium Union Renewal: Assessing Innovations for Union Power in a Globalized Economy, University of Montreal, November 2004.

Camfield, D. 2004a. "Re-Orienting Class Analysis: Working Classes as Historical Formations." Science and Society, Vol. 68, No. 4, pp. 421-446.

Camfield, D. 2004b. Review of Yonaten Reshef and Sandra Rastin, Unions in the Time of Revolution. Relations Industrielles/Industrial Relations, Vol. 59, No. 1, pp. 203-205.

Camfield, D. 2000. “Assessing Resistance in Harris's Ontario, 1995-1999." In Restructuring and Resistance: Canadian Public Policy in an Age of Global Capitalism. M. Burke, C. Mooers and J. Shields (eds.). Halifax: Fernwood, pp. 306-317.

Clarke, S. 1983. "State, Class Struggle, and the Reproduction of Capital." Kapitalistate, Vol. 10/11, pp. 113-134.

Cleaver, H. 1992. "The Inversion of Class Perspective in Marxian Theory: From Valorisation to Self-Valorisation." In Theory and Practice; Vol. 2 of Open Marxism. W. Bonefeld, R. Gunn and K. Psychopedis (eds.). London and Boulder: Pluto, pp. 106-144.

Cranford, C.J and D. Ladd. 2003. "Community Unionism: Organising for Fair Employment in Canada." Just Labour, Vol. 3, pp. 46-59.

Creese, G. 1999. Contracting Masculinity: Gender, Class and Race in a White-Collar Union, 1944-1994. Don Mills: Oxford University Press.

Forrest, A. 1993. "Women and Industrial Relations Theory: No Room in the Discourse." Relations Industrielles/Industrial Relations, Vol. 48, No. 3, pp. 409-438.

Hall, S., Critcher, C., Jefferson, T., Clarke, J., and B. Robert. 1978. Policing the Crisis: Mugging, the State, and Law and Order. London and Basingstoke: Macmillan.

Hebdon, R. and M. Mazerolle. 2003. "Regulating Conflict in Public Sector Labour Relations: The Ontario Experience (1984-1993)." Relations industrielles/Industrial Relations, Vol. 58, No. 4, pp. 667-686. 
Heron, C. 1996. The Canadian Labour Movement: A Brief History. 2nd ed. Toronto: Lorimer.

Hunt, G. 1997. "Sexual Orientation and the Canadian Labour Movement." Relations industrielles/Industrial Relations, Vol. 52, No. 4, pp. 787-809.

Hyman, R. 1989. The Political Economy of Industrial Relations: Theory and Practice in a Cold Climate. London: Macmillan.

Hyman, R. 1975. Industrial Relations: A Marxist Introduction. London and Basingstoke: Macmillan.

Ilcan, S.M, O'Connor, D.M. and M.L. Oliver. 2003. "Contract Governance and the Canadian Public Sector." Relations industrielles/Industrial Relations, Vol. 58, No. 4, pp. 620-643.

Jessop, B. 1994. "Post-Fordism and the State." In Post-Fordism: A Reader. A. Amin (ed.). Oxford: Blackwell, pp. 251-279.

Johnston, P. 1994. Success While Others Fail: Social Movement Unionism and the Public Workplace. Ithaca: ILR Press.

Kelly, J. 1998. Rethinking Industrial Relations: Mobilization, Collectivism and Long Waves. London and New York: Routledge.

Lamb, S. 2004. “The Workers’ Movement Today.” New Socialist, Issue 46, pp. 7-9.

Levesque, M. 2004. E-mail to author. Jan. 30.

Levesque, M. 2003. E-mail to author. Dec. 18.

Lewchuk, W. 2002. "Workload, Work Organization and Health Outcomes: The Ontario Disability Support Program.” Report prepared for the Ontario Public Service Employees Union.

Luxton, M. 2001. "Feminism as a Class Act: Working-Class Feminism and the Women's Movement in Canada." Labour/Le Travail, Vol. 48, pp. 63-88. 
Luxton, M. and E. Reiter. 1997. "Double, Double, Toil and Trouble... Women's Experience of Work and Family in Canada, 1980-1995." In Women and the Canadian Welfare State: Challenges and Change. P.M Evans and G.R Wekerle (eds.). Toronto: University of Toronto Press, pp. 197-221.

McBride, S. and J. Shields. 1997. Dismantling a Nation: The Transition to Corporate Rule in Canada. Halifax: Fernwood.

McElligott, G. 2001. Beyond Service: State Workers, Public Policy, and the Prospects for Democratic Administration. Toronto: University of Toronto Press.

Meiksins, P. 1987. "White Collar Workers and the Process of Class Formation." In Working People and Hard Times: Canadian Perspectives. R. Argue, C. Gannage, and D.W. Livingstone (eds.). Toronto: Garamond, pp. 161-178.

Meiksins, P. 1986. "Beyond the Boundary Question." New Left Review, Vol. 157, pp. 101-120.

Moody, K. 1997. Workers in a Lean World: Unions in the International Economy. London: Verso.

Murray, G. 2002. "Unions in Canada: Strategic Renewal, Strategic Conundrums." In Changing Prospects for Trade Unionism: Comparisons Between Six Countries. P. Fairbrother and G. Griffin (eds.). London: Continuum, pp. 93-136.

Neocleous, M. 1996. Administering Civil Society: Towards a Theory of State Power. London: Macmillan and St. Martin's.

Palmer, B.D. 1992. Working-Class Experience: Rethinking the History of Canadian Labour. 2nd ed. Toronto: McClelland and Stewart.

Panitch, L. and D. Swartz. 2003. From Consent to Coercion: The Assault on Trade Union Freedoms. 3rd ed. Aurora: Garamond.

Parker, M. and M. Gruelle. 1999. Democracy is Power: Rebuilding Unions from the Bottom Up. Detroit: Labor Notes.

Rapaport, D. 1999. No Justice, No Peace: The 1996 OPSEU Strike Against the Harris Government in Ontario. Montreal and Kingston: McGill-Queen's University Press. 
Reshef, Y. and S. Rastin. 2003. Unions in the Time of Revolution: Government Restructuring in Alberta and Ontario. Toronto: University of Toronto Press.

Rose, J.B. 2004. "Public Sector Bargaining: From Retrenchment to Consolidation." Relations industrielles/Industrial Relations, Vol. 59, No. 2, pp. 271-294.

Rose, J.B. and G.N Chaison. 2001. "Unionism in Canada and the United States in the 21st Century: The Prospects for Revival." Relations industrielles/Industrial Relations, Vol. 56, No. 1, pp. 34-62.

Sears, A. 1999. "The 'Lean' State and Capitalist Restructuring: Towards a Theoretical Account." Studies in Political Economy, Vol. 59, pp. 91-114.

Séguin, R. with I. Peritz. 2003. "General-strike threat rising in Quebec, unions warn." Globe and Mail, Dec. 12, p. A8.

Shields, J. and B M. Evans. 1998. Shrinking the State: Globalization and Public Administration "Reform. ”Halifax: Fernwood.

Statistics Canada. 2003. Public Sector Statistics. Financial Management System 2002 -2003. (Statistics Canada Catalogue no. 68-213-XIE).

Swimmer, G. 2001. Public-Sector Labour Relations in an Era of Restraint and Restructuring. Don Mills: Oxford University Press.

Teeple, G. 2000. Globalization and the Decline of Social Reform: Into the Twenty-First Century. Toronto: Garamond.

Thompson, M. and B. Bemmels. 2003. "British Columbia: The Parties Match the Mountains." In Beyond the National Divide: Regional Dimensions of Industrial Relations. M. Thompson, J.B Rose and A.E Smith (eds.). Montreal: McGill Queen's University Press, pp. 97-127.

Tufts, S. 1998. "Community Unionism in Canada and Labor's (Re)organization of Space.” Antipode, Vol. 30, No. 3, pp. 227-250.

Warrian, P. 1996. Hard Bargain: Transforming Public Sector Labour-Management Relations. Toronto: McGilligan. 
Warskett, R. 1996. "The Politics of Difference and Inclusiveness within the Canadian Labour Movement." Economic and Industrial Democracy, Vol. 17, pp. 587-625.

White, J.P and R. Janzen. 2000. "The Industrial Relations Implications of Privatization: The Case of Canada Post." Relations industrielles/Industrial Relations, Vol. 55, No. 1, pp. 36-55.

White, J. 1993. Sisters and Solidarity: Women and Unions in Canada. Toronto: Thompson Educational Publishing.

Yates, C. 2000. "Staying the Decline in Union Membership: Union Organizing in Ontario, 1985-1999." Relations industrielles/Industrial Relations, Vol. 55, No. 4, pp. 640-674.

Zerowork Collective. 1992. "Introduction to Zerowork I." In Midnight Oil: Work, Energy, War, 1973-1992. Midnight Notes Collective. Brooklyn: Autonomedia. 